\title{
Patient satisfaction with clinical pharmacy services and the affecting factors: a literature review
}

\author{
Yuliandani Yuliandani ${ }^{1}$, Sofa Dewi Alfian ${ }^{1,2}$, Irma Melyani Puspitasari ${ }^{1,2}$ \\ 1 Department of Pharmacology and Clinical Pharmacy, Faculty of Pharmacy, Universitas Padjadjaran, Sumedang, Indonesia \\ 2 Center of Excellence in Higher Education for Pharmaceutical Care Innovation, Universitas Padjadjaran, Sumedang, Indonesia \\ Corresponding author: Irma Melyani Puspitasari (irma.melyani@unpad.ac.id)
}

Received 8 January 2022 • Accepted 13 February 2022 • Published 8 March 2022

Citation: Yuliandani Y, Alfian SD, Puspitasari IM (2022) Patient satisfaction with clinical pharmacy services and the affecting factors: a literature review. Pharmacia 69(1): 227-236. https://doi.org/10.3897/pharmacia.69.e80261

\begin{abstract}
Service quality is measured to assess the consistency of medical services provided to fulfill patient expectations. This article provides an overview of patient satisfaction with clinical pharmacy services and the influencing factors. A literature search from MEDLINE and EBSCO databases was performed with the keywords "patient satisfaction", "pharmacy service", "hospital pharmacy service", and "clinical pharmacy service". The inclusion criteria for articles are original articles, full papers, articles in English, and published in 2011-2021. A total of 25 articles from 1,118 articles discussed patient satisfaction with clinical pharmacy services such as counseling, drug therapy monitoring, patient support programs, and pharmaceutical care. Generally, patients are satisfied with clinical pharmacy services such as counseling, drug therapy monitoring, patient support programs, and pharmaceutical care. The most influencing factors with clinical pharmacy services are the quality, convenience, ease of information, and confidence in pharmacist competence. Pharmacists should equip themselves with the appropriate knowledge and competencies in clinical pharmacy services for benefits their patients.
\end{abstract}

\section{Keywords}

counseling, drug therapy monitoring, pharmaceutical care, patient support program

\section{Introduction}

Patient satisfaction measures the consistency of health services provided to fulfill patient expectations (Kabba et al. 2021) and it is beneficial for assessing communication patterns (Schoenfelder et al. 2011). This assessment will affect the service program to improve the health system. Previous studies showed that satisfied patients are expected to cooperate with health care practitioners, participate in their health care, adhere to medication regimens, and have better health outcomes (Malewski et al. 2015).

In experiencing health care, patients need professional health assistance that is easily accessible. Therefore, pharmacists are one health care professionals selected to accompany patients during the treatment period (Miller and Goodman 2016). They can conduct activities related to public health promotion to build patient trust as a form of pharmacist concern for well-being (Hillier-Brown et al. 2017). Pharmacists can provide clinical services in carrying out their practice of providing services to patients (Malewski et al. 2015).

Clinical pharmacy service provides rational drug therapy that is safe, precise, and cost-effective (Ansari 2017). Patients will get satisfaction based on how well pharmaceutical service practices meet their expectations and needs (Chou et al. 2019). The evaluation used to monitor the quality is 
to assess patient satisfaction with the care services received by patients (Garattini and Padula 2018). Therefore, pharmacists should know the right time to discuss with patients because they are responsible for fulfilling needs and answering questions (Al-Arifi 2012). They also equipped with motivation and good technical training will increase the effectiveness of quality health care (Kabba et al. 2021).

Previous studies explained that patient satisfaction impacts pharmaceutical services, including patient compliance to the treatment provided, improving treatment outcomes and patient loyalty to healthcare providers (Kabba et al. 2021). A review article in 2019 discussed patient satisfaction with pharmacy services (Gulcan and Aransiola 2019). It showed that the determinants were regulated through the services provided by pharmacists. However, the article did not discuss the types of clinical pharmacy services and the influencing factors. Therefore, this paper will give an overview of patient satisfaction with clinical pharmacy services and the influencing factors.

\section{Methods}

\section{Data search}

The literature search on the MEDLINE and EBSCO databases was conducted in May-June 2021. The keywords used included "patient satisfaction", "pharmacy service", "hospital pharmacy service", and "clinical pharmacy service". The literature search report of flow diagram followed to the the Preferred Reporting Items for Systematic Reviews and Meta-Analyses (PRISMA).

\section{Study selection}

The inclusion criteria for articles are original articles, full papers, article in English, and published in 2011-2021. Articles excluded have criteria that do not discuss clinical pharmacy service and do not contain the desired keywords.

\section{Article extraction}

The extracted data are references containing the main author's name and year of publication, country, participants, the number of participants, place of service, type of clinical pharmacy service, study design, satisfaction measurement instrument, factors influencing patient satisfaction, results, and funding sources.

\section{Results and discussion}

Fig. 1 shows the PRISMA flow diagram of article selection process. The selection was made based on predetermined keywords resulting in a total of 1,118 articles, where 441 were sourced from MEDLINE, and 677 were from EBSCO database. The initial selection process was followed by

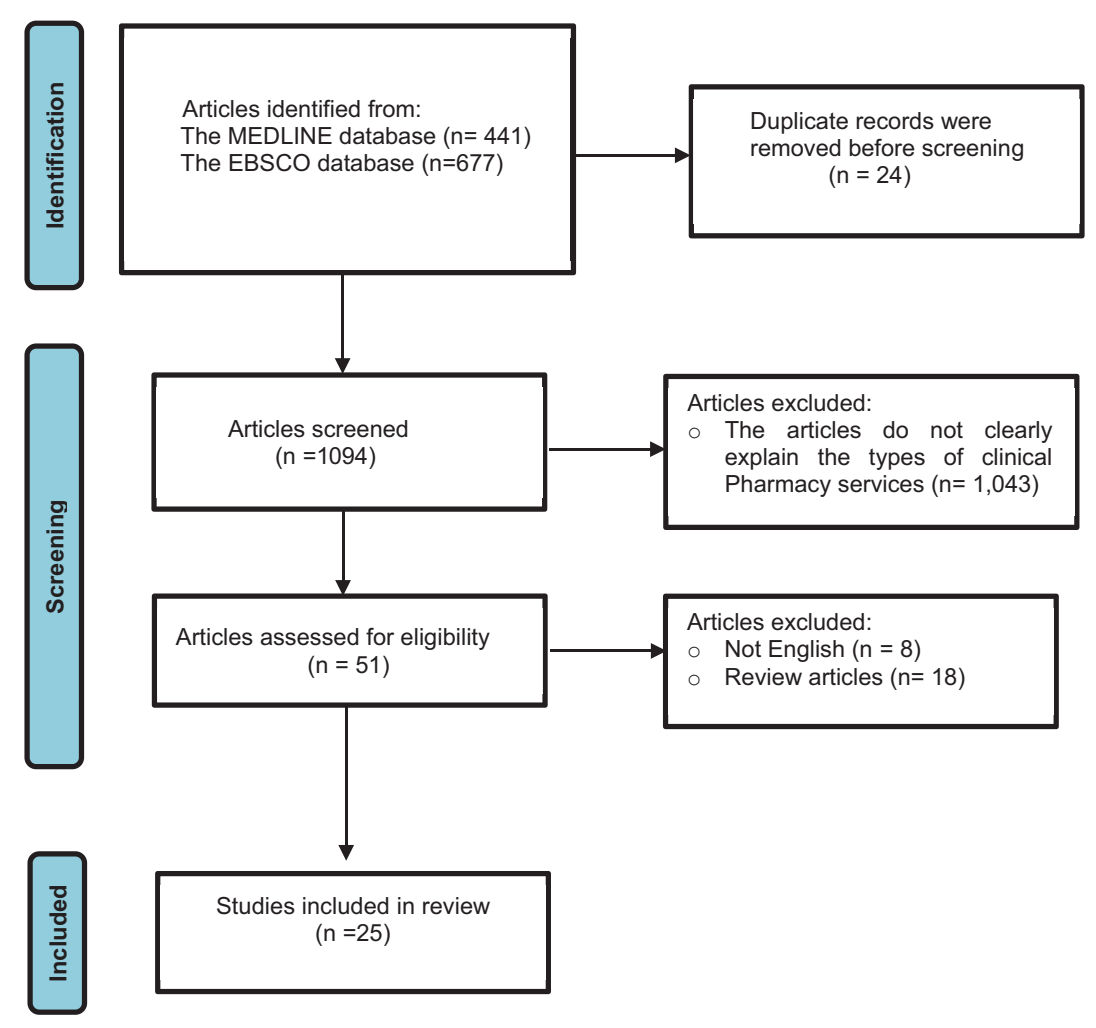

Figure 1. PRISMA flow diagram of the literature search. 
removing duplicate articles until 1,094 articles were obtained. Furthermore, a second selection was carried out by excluding 1,069 articles unrelated to the inclusion and exclusion criteria. Therefore, 25 articles were obtained about patient satisfaction with clinical pharmacy services.

Table 1 shows 25 articles on patient satisfaction with clinical pharmacy services. The studies were conducted worldwide with the number of participants more than 41,000 participants at hospitals, primary health care services, pharmacies, and community pharmacies. The service type of clinical pharmacy includes patient counseling, drug therapy monitoring, patient support program, and pharmaceutical care services. Most studies were conducted with cross-sectional design through self-reported questionnaires or interviews. Different types self-reported questionnaire such as modified questionnaire from previous studies, Medication Adherence Scale-8 (MMAS-8) questionnaire, Diabetes Medication Satisfaction (DiabMedSat) questionnaire, The Leeds Satisfaction Questionnaire (LSQ), Patient Satisfaction Feedback (PSF) questionnaire, The Consumer Assessment of Health Plans Survey (CAHPS), and The Pesquisa Nacional sobre Acesso, Utilização e Promoção do Uso Racional de Medicamentos -Serviços (PNAUM - National Survey on Access, Use and Promotion of Rational Use of Medicines Services), were used to assess patients satisfaction related to pharmacy facility, clinical pharmacy services, role of pharmacist, communication, and pharmaceutical care services.

\section{Patient satisfaction with counseling services}

Table 2 presents 9 articles on patient satisfaction with counseling services. Generally, the patients showed high satisfaction with clinical pharmacy services. Patient satisfaction with counseling in Saudi Arabia was reported to have different levels. According to the study conducted by Al-Arifi. (2012), most patients were very satisfied with the performance and professionalism of pharmacists with satisfaction indicators such as the role in counseling, patient compliance, and providing appropriate drug information. The higher the frequency of counseling the greater the satisfaction rating. However, there are several barriers counseling moments as include lack of privacy and an inadequate number of qualified pharmacists (Al-Arifi 2012).

Another study from Saudi Arabia reported that the level of is low patient satisfaction with score was $2.97 \pm 0.65$ out of 5 scale (Alotaibi et al. 2021). The influencing factors were pharmacy facilities, pharmacy services, and counseling. Most of the patient's reported that they were not satisfied with history taking practice by the pharmacists (Score: $3.17 \pm 1.60$ ), provision of instructions for side effects or interactions (Score: 3.08 \pm 1.64 ), and dissemination of information on storage conditions (score: $3.11 \pm 1.63$ ). Other causes are to

Table 1. List of patient satisfaction articles on clinical pharmacy services.

\begin{tabular}{|c|c|c|c|c|c|c|c|}
\hline No & $\begin{array}{l}\text { Authors, Country, } \\
\text { Year } \\
\end{array}$ & Participant & $\begin{array}{c}\text { Number of } \\
\text { participants }\end{array}$ & $\begin{array}{l}\text { Service } \\
\text { Place }\end{array}$ & Service Type & Study design & Instrument \\
\hline 1 & $\begin{array}{l}\text { Alotaibi NH et al., } \\
\text { Saudi Arabia, } 2021\end{array}$ & $\begin{array}{c}\text { Outpatient } \\
\text { pharmacies of various } \\
\text { public hospitals }\end{array}$ & $\mathrm{n}=746$ & Hospitals & Counseling & $\begin{array}{c}\text { Cross- } \\
\text { sectional study }\end{array}$ & $\begin{array}{l}\text { A } 23 \text {-items questionnaire that measure patient satisfaction } \\
\text { related to pharmacy facilities and pharmacy services with } \\
\text { 5-items Likert scale. }\end{array}$ \\
\hline 2 & $\begin{array}{l}\text { Al-Arifi MN, } \\
\text { Saudi Arabia, } 2012\end{array}$ & $\begin{array}{l}\text { Patients attending } \\
\text { community } \\
\text { pharmacies. }\end{array}$ & $\mathrm{n}=1,699$ & $\begin{array}{l}\text { Community } \\
\text { pharmacies }\end{array}$ & Counseling & $\begin{array}{l}\text { Cross- } \\
\text { sectional study }\end{array}$ & $\begin{array}{l}\text { The questionnaire composed of } 8 \text { items about patients' } \\
\text { views and satisfaction with the pharmacists' role in the } \\
\text { current community pharmacy practice }\end{array}$ \\
\hline 3 & $\begin{array}{l}\text { Alkhoshaiban A, } \\
\text { Saudi Arabia, } 2019\end{array}$ & $\begin{array}{l}\text { Type II diabetic } \\
\text { patients. }\end{array}$ & $\mathrm{n}=102$ & Hospitals & Counseling & $\begin{array}{c}\text { The } \\
\text { comparative } \\
\text { study used } \\
\text { Longitudinal } \\
\text { method }\end{array}$ & $\begin{array}{l}\text { Medication Adherence Scale-8 (MMAS-8) and Diabetes } \\
\text { Medication Satisfaction (DiabMedSat) questionnaires }\end{array}$ \\
\hline 4 & $\begin{array}{l}\text { Hale A et al., } \\
\text { Australia } 2015\end{array}$ & $\begin{array}{l}\text { Patients scheduled for } \\
\text { elective surgery }\end{array}$ & $\mathrm{n}=200$ & $\begin{array}{l}\text { A tertiary } \\
\text { Hospital }\end{array}$ & Counseling & $\begin{array}{l}\text { Cross- } \\
\text { sectional study }\end{array}$ & $\begin{array}{l}\text { Surveys containing } 12 \text { and } 25 \text { questions with a Likert scale } \\
\text { responses that investigate patient satisfaction and views of } \\
\text { collaborative doctor-pharmacist prescribing. }\end{array}$ \\
\hline 5 & $\begin{array}{l}\text { Iancu ME, et al. } \\
\text { Romania, } 2014\end{array}$ & $\begin{array}{l}\text { Patients, relatives } \\
\text { and caregivers who } \\
\text { obtained counselling } \\
\text { by pharmacists. }\end{array}$ & $\mathrm{n}=3,303$ & Pharmacies & Counseling & $\begin{array}{l}\text { Prospective } \\
\text { survey design }\end{array}$ & $\begin{array}{l}\text { A } 16 \text { items questionnaire regarding the counseling } \\
\text { provided by the pharmacist during the visit. }\end{array}$ \\
\hline 6 & $\begin{array}{l}\text { Munro L, et al., } \\
\text { Canada, } 2020\end{array}$ & $\begin{array}{l}\text { Patients at the } \\
\text { oncology clinic }\end{array}$ & $\mathrm{n}=35$ & Hospital & Counseling & $\begin{array}{l}\text { Cross- } \\
\text { sectional study }\end{array}$ & $\begin{array}{l}\text { Surveys and patient interviews with a total } 20 \text { items } \\
\text { questions on their perceptions of the importance of the } \\
\text { clinical pharmacy services and their satisfaction with the } \\
\text { services provided. }\end{array}$ \\
\hline 7 & $\begin{array}{l}\text { Hall JJ, et al., } \\
\text { Canada, } 2016\end{array}$ & $\begin{array}{l}\text { Rheumatology clinic } \\
\text { patients }\end{array}$ & $\mathrm{n}=62$ & Hospital & Counseling & $\begin{array}{c}\text { Cross- } \\
\text { sectional study }\end{array}$ & $\begin{array}{l}\text { The Leeds Satisfaction Questionnaire (LSQ) with a } 5 \\
\text { points of Likert scale to measure patient satisfaction. }\end{array}$ \\
\hline 8 & $\begin{array}{l}\text { Fesharaki F, Iran, } \\
2019\end{array}$ & $\begin{array}{l}\text { Patients who waiting } \\
\text { for their medicine }\end{array}$ & $\mathrm{n}=326$ & Pharmacies & Counseling & $\begin{array}{l}\text { Cross- } \\
\text { sectional study }\end{array}$ & $\begin{array}{l}\text { A } 36 \text {-items questionnaire with a } 5 \text {-item Likert scale that } \\
\text { ask the patient about the nonverbal communication of the } \\
\text { pharmacist and their satisfaction. }\end{array}$ \\
\hline 9 & $\begin{array}{l}\text { Alshayban DM, et } \\
\text { al., Saudi } \\
\text { Arabia } 2020\end{array}$ & $\begin{array}{l}\text { Chronic and acute } \\
\text { disease patients }\end{array}$ & $\mathrm{n}=531$ & Hospitals & Counseling & $\begin{array}{l}\text { Cross- } \\
\text { sectional study }\end{array}$ & $\begin{array}{l}\text { Arabic version of Patient Satisfaction Feedback (PSF) } \\
\text { questionnaire that measured satisfaction as well as } \\
\text { willingness-to-pay for a pharmacist counseling session. }\end{array}$ \\
\hline 10 & $\begin{array}{l}\text { Martin and Faber, } \\
\text { United States of } \\
\text { America } 2016\end{array}$ & $\begin{array}{l}\text { Patients receiving } \\
\text { Hepatitis C Virus } \\
\text { (HCV) treatment }\end{array}$ & $\mathrm{n}=64$ & Hospital & $\begin{array}{l}\text { Drug therapy } \\
\text { monitoring }\end{array}$ & $\begin{array}{c}\text { Cross- } \\
\text { sectional study }\end{array}$ & $\begin{array}{l}\text { A patient satisfaction survey consists of } 20 \text { questions } \\
\text { that assess the patient satisfaction with the health care } \\
\text { provider(s) including clinical pharmacist during the } \\
\text { management of HCV therapy. }\end{array}$ \\
\hline
\end{tabular}




\begin{tabular}{|c|c|c|c|c|c|c|c|}
\hline No & $\begin{array}{c}\text { Authors, Country, } \\
\text { Year }\end{array}$ & Participant & $\begin{array}{c}\text { Number of } \\
\text { participants }\end{array}$ & $\begin{array}{l}\text { Service } \\
\text { Place }\end{array}$ & Service Type & Study design & Instrument \\
\hline 11 & $\begin{array}{l}\text { Reich CM et al., } \\
\text { United States of } \\
\text { America, } 2018\end{array}$ & $\begin{array}{l}\text { Patients diagnosed } \\
\text { with psychiatric } \\
\text { disorders }\end{array}$ & $\mathrm{n}=240$ & Hospital & $\begin{array}{l}\text { Drug therapy } \\
\text { monitoring }\end{array}$ & $\begin{array}{c}\text { Cross- } \\
\text { sectional study }\end{array}$ & $\begin{array}{l}\text { A 19-item questionnaire that measure patient satisfaction } \\
\text { with a 5-point scale. }\end{array}$ \\
\hline 12 & $\begin{array}{l}\text { Crespo and } \\
\text { Tyszka, Canada, } \\
2016\end{array}$ & $\begin{array}{l}\text { Patients receiving } \\
\text { chemotherapy }\end{array}$ & $\mathrm{n}=112$ & Hospital & $\begin{array}{l}\text { Drug therapy } \\
\text { monitoring }\end{array}$ & $\begin{array}{l}\text { Cross- } \\
\text { sectional study }\end{array}$ & $\begin{array}{l}\text { The } 20 \text {-item survey with a Likert-scale questions that } \\
\text { assessed satisfaction with clinical pharmacy services. }\end{array}$ \\
\hline 13 & $\begin{array}{l}\text { Beyene K et al., } \\
\text { New Zealand, } \\
2020\end{array}$ & $\begin{array}{l}\text { Patients taking } \\
\text { warfarin }\end{array}$ & $\mathrm{n}=305$ & Pharmacies & $\begin{array}{l}\text { Drug therapy } \\
\text { monitoring }\end{array}$ & $\begin{array}{c}\text { Cross- } \\
\text { sectional study }\end{array}$ & $\begin{array}{l}\text { The } 36 \text {-item questionnaire with a } 5 \text {-item Likert scale to } \\
\text { measure patient satisfaction with community pharmacist- } \\
\text { led anticoagulation services. }\end{array}$ \\
\hline 14 & $\begin{array}{l}\text { Bezuidenhout et } \\
\text { al., South Africa, } \\
2014\end{array}$ & $\begin{array}{l}\text { Patients with } \\
\text { antiretrovirals } \\
\text { treatment }\end{array}$ & $\mathrm{n}=300$ & Hospital & $\begin{array}{l}\text { Drug therapy } \\
\text { monitoring }\end{array}$ & $\begin{array}{l}\text { Cross- } \\
\text { sectional study }\end{array}$ & $\begin{array}{c}\text { An interview with using a standardised structured } \\
\text { questionnaire to assess patient satisfaction on general } \\
\text { facility and healthcare provision, communication, and } \\
\text { medicine management. }\end{array}$ \\
\hline 15 & $\begin{array}{l}\text { Chou YC et al., } \\
\text { Taiwan, } 2019\end{array}$ & $\begin{array}{l}\text { Patients who received } \\
\text { medical care }\end{array}$ & $\mathrm{n}=741$ & Hospital & $\begin{array}{l}\text { Drug therapy } \\
\text { monitoring }\end{array}$ & $\begin{array}{l}\text { Cross- } \\
\text { sectional study }\end{array}$ & $\begin{array}{l}\text { The 5-item questionnaire to investigate patients' } \\
\text { perceptions about their trust, satisfaction, and cooperation } \\
\text { with clinical pharmacists. }\end{array}$ \\
\hline 16 & $\begin{array}{l}\text { Sites BD et al., } \\
\text { Lebanese } 2018\end{array}$ & $\begin{array}{l}\text { Patients with } \\
\text { musculoskeletal } \\
\text { conditions }\end{array}$ & $\mathrm{n}=19,566$ & Hospital & $\begin{array}{l}\text { Drug therapy } \\
\text { monitoring }\end{array}$ & $\begin{array}{c}\text { Cross- } \\
\text { sectional study }\end{array}$ & $\begin{array}{l}\text { The Consumer Assessment of Health Plans Survey } \\
\text { (CAHPS) from the the Medical Expenditure Panel Survey } \\
\text { (MEPS) data. }\end{array}$ \\
\hline 17 & $\begin{array}{l}\text { Hatton J et al., } \\
\text { United States of } \\
\text { America } 2017\end{array}$ & $\begin{array}{l}\text { Patients who received } \\
\text { care from the face-to- } \\
\text { face or clinical video } \\
\text { teleconferencing } \\
\text { (CVT) pharmacy } \\
\text { clinic. }\end{array}$ & $\mathrm{n}=57$ & Hospital & $\begin{array}{l}\text { Patient support } \\
\text { program }\end{array}$ & $\begin{array}{c}\text { Cross- } \\
\text { sectional study }\end{array}$ & $\begin{array}{l}\text { The } 10 \text {-item, patient self-reported questionnaire to } \\
\text { evaluate patient satisfaction with pharmacist-provided } \\
\text { consultations via CVT. }\end{array}$ \\
\hline 18 & $\begin{array}{l}\text { Mooney EV et al., } \\
\text { United States of } \\
\text { America, } 2018\end{array}$ & $\begin{array}{l}\text { Patients receiving } \\
\text { LAIA (Long- } \\
\text { Acting Injectable } \\
\text { Antipsychotics) }\end{array}$ & $\mathrm{n}=161$ & Pharmacies & $\begin{array}{l}\text { Patient support } \\
\text { program }\end{array}$ & $\begin{array}{c}\text { Prospective } \\
\text { survey design }\end{array}$ & $\begin{array}{l}\text { A survey consisted } 4 \text { sections that assessed patients' } \\
\text { satisfaction with pharmacist- administered LAIAs in the } \\
\text { community pharmacy. }\end{array}$ \\
\hline 19 & $\begin{array}{l}\text { Bourdin A et al. } \\
\text { Switzerland, } 2020\end{array}$ & $\begin{array}{l}\text { Patients who } \\
\text { participated in } \\
\text { Fingolimod Patient } \\
\text { Support Program } \\
\text { (F-PSP) }\end{array}$ & $\mathrm{n}=17$ & Hospital & $\begin{array}{l}\text { Patient support } \\
\text { program }\end{array}$ & $\begin{array}{c}\text { Cross- } \\
\text { sectional study }\end{array}$ & $\begin{array}{l}\text { A qualitative study with face-to-face semistructured } \\
\text { interviews to explore the satisfaction, experiences and } \\
\text { perceptions regarding the F-PSP. }\end{array}$ \\
\hline 20 & $\begin{array}{l}\text { Takaki H et al, } \\
\text { Japan } 2015\end{array}$ & $\begin{array}{l}\text { Patients who visit } \\
\text { the pharmacy and } \\
\text { receive prescription } \\
\text { medication }\end{array}$ & $\mathrm{n}=407$ & Pharmacies & $\begin{array}{l}\text { Pharmaceutical } \\
\text { care }\end{array}$ & $\begin{array}{c}\text { Cross- } \\
\text { sectional study }\end{array}$ & $\begin{array}{l}\text { A questionnaire package using four items and five } \\
\text { response categories was used to measure overall } \\
\text { satisfaction with pharmaceutical care services. }\end{array}$ \\
\hline 21 & $\begin{array}{l}\text { Soeiro OM et al., } \\
\text { Brazil, } 2017\end{array}$ & $\begin{array}{l}\text { Patients in primary } \\
\text { health care services }\end{array}$ & $\mathrm{n}=8,803$ & $\begin{array}{l}\text { Primary } \\
\text { health care } \\
\text { services }\end{array}$ & $\begin{array}{c}\text { Pharmaceutical } \\
\text { care }\end{array}$ & $\begin{array}{c}\text { Cross- } \\
\text { sectional study }\end{array}$ & $\begin{array}{l}\text { The Pesquisa Nacional sobre Acesso, Utilização e } \\
\text { Promoção do Uso Racional de Medicamentos - Serviços } \\
\text { (PNAUM - National Survey on Access, Use and } \\
\text { Promotion of Rational Use of Medicines - Services) that } \\
\text { measure patients satisfaction with pharmaceutical care } \\
\text { services. }\end{array}$ \\
\hline 22 & $\begin{array}{l}\text { El-Sharif SI et al., } \\
\text { Uni Emirat Arab, } \\
2017\end{array}$ & $\begin{array}{l}\text { Patients with } \\
\text { medical and non- } \\
\text { medical educational } \\
\text { background }\end{array}$ & $\mathrm{n}=375$ & Pharmacy & $\begin{array}{c}\text { Pharmaceutical } \\
\text { care }\end{array}$ & $\begin{array}{c}\text { Cross- } \\
\text { sectional study }\end{array}$ & $\begin{array}{l}\text { Modified questionnaire from the Community Pharmacy } \\
\text { Patient Questionnaire (PSNC), United Kingdom and } \\
\text { surveys of patient satisfaction with pharmaceutical } \\
\text { services in rural areas, Ministry of Health in Saudi Arabia } \\
\text { that measure patients satisfaction with pharmaceutical } \\
\text { care services. }\end{array}$ \\
\hline 23 & $\begin{array}{l}\text { Abebe TB et al., } \\
\text { Ethiopia } 2016\end{array}$ & HIV/AIDS patients & $\mathrm{n}=291$ & Hospital & $\begin{array}{l}\text { Pharmaceutical } \\
\text { care }\end{array}$ & $\begin{array}{c}\text { Cross- } \\
\text { sectional study }\end{array}$ & $\begin{array}{l}\text { Data were collected using structured questionnaires } \\
\text { measuring patients expectation and satisfaction of } \\
\text { pharmaceutical care using a Likert scale of 1-5 through } \\
\text { face-to-face interviews. }\end{array}$ \\
\hline 24 & $\begin{array}{l}\text { Ali HS et al, Uni } \\
\text { Emirat Arab, } 2019\end{array}$ & $\begin{array}{l}\text { All patients who } \\
\text { come to the } \\
\text { pharmacy }\end{array}$ & $\mathrm{n}=210$ & $\begin{array}{l}\text { Community } \\
\text { pharmacies }\end{array}$ & $\begin{array}{c}\text { Pharmaceutical } \\
\text { care }\end{array}$ & $\begin{array}{c}\text { Cross- } \\
\text { sectional study }\end{array}$ & $\begin{array}{l}\text { A 20-item questionnaire regarding the patients' perception } \\
\text { towards pharmacist 'performance } \\
\text { and satisfaction with the pharmaceutical services provided. }\end{array}$ \\
\hline \multirow[t]{2}{*}{25} & $\begin{array}{l}\text { Minarikova et al., } \\
\text { Slovakia, } 2016\end{array}$ & $\begin{array}{l}\text { Patients aged } 40 \text { years } \\
\text { and over }\end{array}$ & $\mathrm{n}=2844$ & $\begin{array}{l}\text { Community } \\
\text { pharmacies }\end{array}$ & $\begin{array}{l}\text { Pharmaceutical } \\
\text { care }\end{array}$ & $\begin{array}{c}\text { Cross- } \\
\text { sectional study }\end{array}$ & $\begin{array}{l}\text { A } 29 \text {-item questionnaire with a } 5 \text {-item Likert scale } \\
\text { to measure the extent of patient satisfaction with the } \\
\text { pharmaceutical care provided } \\
\text { in community pharmacies. }\end{array}$ \\
\hline & & & $\begin{array}{c}\text { Total } \\
\mathrm{n}=41.494\end{array}$ & & & & \\
\hline
\end{tabular}

limited number of pharmacists and pharmacy staff in the hospitals, increased workload, lack of continuous education for pharmacy service providers as well as lower standards of pharmacy services and less attention of regional health departments on pharmacy standards and practice (Alotaibi et al. 2021).
In addition, the study conducted by Alkhoshaiban A et al. (2019) on 102 patients with type II diabetes showed that the intervention program has improved medication adherence, satisfaction, and HbA1c level among patients with type II diabetes. Medication adherence, satisfaction, and HbAlc level were all associated with gender. The improvement 
Table 2. Patient satisfaction with counseling services.

\begin{tabular}{|c|c|c|c|c|c|}
\hline Authors & Country & Participants & Factors that affect satisfaction & Result & Funding \\
\hline $\begin{array}{l}\text { Alotaibi NH et al. } \\
2021\end{array}$ & $\begin{array}{c}\text { Saudi } \\
\text { Arabia }\end{array}$ & 746 patients & Quality of pharmacy services, pharmacy facilities & $\begin{array}{l}\text { Approximately one-half of the patients were not } \\
\text { satisfied with outpatient pharmacy services. The } \\
\text { overall satisfaction score was } 2.97 \pm 0.65 \text { out of } \\
5 \text { scale. }\end{array}$ & $\begin{array}{c}\text { Not } \\
\text { applicable }\end{array}$ \\
\hline Al-Arifi MN, 2012 & $\begin{array}{c}\text { Saudi } \\
\text { Arabia }\end{array}$ & 1,699 patients & $\begin{array}{l}\text { The role of pharmacists in counseling patient } \\
\text { compliance and providing drug information }\end{array}$ & $\begin{array}{l}\text { The patients showed better satisfaction, perception } \\
\text { and appreciation of the pharmacists' role in the } \\
\text { health care team. }\end{array}$ & $\begin{array}{c}\text { Not } \\
\text { applicable }\end{array}$ \\
\hline $\begin{array}{l}\text { Alkhoshaiban A et } \\
\text { al. } 2019\end{array}$ & $\begin{array}{l}\text { Saudi } \\
\text { Arabia }\end{array}$ & $\begin{array}{l}102 \text { type II diabetic } \\
\text { patients (T2DM) }\end{array}$ & $\begin{array}{l}\text { Treatment adherence and satisfaction of elderly } \\
\text { patients, the impact of adherence to HbAlc }\end{array}$ & $\begin{array}{l}\text { The intervention program has improved } \\
\text { medication adherence, satisfaction, and HbA1c } \\
\text { level among elderly patients with T2DM. }\end{array}$ & $\begin{array}{c}\text { Not } \\
\text { applicable }\end{array}$ \\
\hline $\begin{array}{l}\text { Alshayban DM et } \\
\text { al. } 2020\end{array}$ & $\begin{array}{c}\text { Saudi } \\
\text { Arabia }\end{array}$ & $\begin{array}{l}531 \text { patients with } \\
\text { chronic and acute } \\
\text { disease }\end{array}$ & $\begin{array}{l}\text { Quality of service, duration of counseling, } \\
\text { pharmacist knowledge }\end{array}$ & $\begin{array}{c}\text { Most patients }(43.9 \%) \text { were satisfied with } \\
\text { pharmacist counseling and average satisfaction } \\
\text { rating was } 7.87 \pm \\
1.99 / 10 .\end{array}$ & $\begin{array}{c}\text { Not } \\
\text { applicable }\end{array}$ \\
\hline Hale A et al. 2015 & Australia & $\begin{array}{l}200 \text { patients } \\
\text { scheduled for } \\
\text { elective surgery }\end{array}$ & $\begin{array}{c}\text { Consultation satisfaction from doctor } \\
\text { collaboration and patient satisfaction with } \\
\text { prescribing pharmacists }\end{array}$ & $\begin{array}{l}\text { Most of the patients had a high satisfaction with } \\
\text { pharmacist prescriber consultations. }\end{array}$ & $\begin{array}{c}\text { Not } \\
\text { applicable }\end{array}$ \\
\hline $\begin{array}{l}\text { Iancu ME et al. } \\
2014\end{array}$ & Romania & $\begin{array}{l}\text { Patients, relatives } \\
\text { and caregivers who } \\
\text { obtained counselling } \\
\text { by pharmacists. }\end{array}$ & $\begin{array}{l}\text { Patient education and counseling satisfaction, } \\
\text { counseling on expired drug information }\end{array}$ & $\begin{array}{l}\text { A great proportion of the respondents received } \\
\text { all the information they needed from the } \\
\text { pharmacist and } \\
\text { were satisfied in the highest degree by the } \\
\text { interview with } \\
\text { the pharmacist. }\end{array}$ & $\begin{array}{c}\text { Not } \\
\text { applicable }\end{array}$ \\
\hline $\begin{array}{l}\text { Munro L et al. } \\
2020\end{array}$ & Canada & $\begin{array}{l}35 \text { patients at the } \\
\text { oncology clinic at }\end{array}$ & $\begin{array}{l}\text { Convenience and easiness, medication } \\
\text { information, communication between patients } \\
\text { and clinical pharmacists }\end{array}$ & $\begin{array}{l}\text { Patients are very satisfied with the average } \\
\text { satisfaction score from } 5.97 \text { to } 6.70 \text {, out of } 7 \\
\text { possibilities. }\end{array}$ & $\begin{array}{c}\text { Not } \\
\text { applicable }\end{array}$ \\
\hline Hall JJ et al. 2016 & Canada & $\begin{array}{l}62 \text { patients at } \\
\text { rheumatology clinic }\end{array}$ & $\begin{array}{l}\text { General satisfaction, providing information, } \\
\text { empathy for patients, Service techniques as well } \\
\text { as competencies, ethics, and communication }\end{array}$ & $\begin{array}{l}\text { Patient satisfaction in the collaborative care group } \\
\text { was consistently higher across all dimensions. }\end{array}$ & $\begin{array}{c}\text { Not } \\
\text { applicable }\end{array}$ \\
\hline Fesharaki F, 2019 & Iran & 326 patients & $\begin{array}{l}\text { Counseling using nonverbal communication } \\
\text { (pharmacist tone of voice, body language), } \\
\text { waiting time, Pharmacy atmosphere }\end{array}$ & $\begin{array}{c}\text { In community pharmacies, nonverbal } \\
\text { communication are significantly related to patient } \\
\text { satisfaction. }\end{array}$ & $\begin{array}{c}\text { Not } \\
\text { applicable }\end{array}$ \\
\hline
\end{tabular}

in medication adherence, satisfaction, and HbAlc level demonstrates the pharmacist's critical role in the patient's overall health management (Alkhoshaiban et al. 2019).

The study conducted by Hale A et al. (2016) in Australia on 200 patients scheduled for surgery reported that most of the patients had a high satisfaction with pharmacist prescriber consultations. This is because more than $97 \%$ patients were satisfied with counseling services in consultations with pharmacists. These are all key components in forming an effective partnership with a patient and adherence with treatment plans. (Hale et al. 2016).

In Romania, Iancu et al. (2014) study also showed a high level of patient satisfaction. The majority of respondents $(47.65 \%)$ estimated that they spent 5-10 minutes with the pharmacist. $95.85 \%$ of patients said the pharmacist provided them with all of the information they required, and 76.51 percent of participants said they were very satisfied with the pharmacist interview ( 5 on a $1-5$ scale). The pharmacist provided the majority of the respondents with all of the information they need, and the interview with the pharmacist left them extremely satisfied. The counseling activities are carried out by pharmacists in a very professional manner, in accordance with patient feedback during counseling. Patients received advice on drug administration information such as the route of administration, how to take the drug with food, the dose used, and the length of treatment. (Iancu et al. 2014).
Study conducted in Canada in 2021 on 35 patients experiencing anticancer therapy showed very high patient satisfaction with counseling services, where the average satisfaction score was 5.90-6.70 out of 7 possibilities (Munro et al. 2021). Patient satisfaction is based on indicators of comfort during counseling, ease of delivery of treatment information, and good communication between patients and pharmacists (Munro et al. 2021). The pharmacist provided the majority of respondents with all of the information they required, and the interview left them extremely satisfied with their relationships with oncology pharmacists: the feeling of being supported by the pharmacist may not only improve emotional well-being but also improve the quality of care received if patients communicate with pharmacists about emerging issues and adhere to recommended pharmaceutical treatments (Munro et al. 2021). In addition, previous study conducted on 62 female patients in a rheumatology clinic showed high patient satisfaction with indicators of providing information, service techniques, ethical competence, and good communication by pharmacists to patients (Hall et al. 2017).

In Iran, study conducted on 326 patients showed high patient satisfaction (Fesharaki 2019). This satisfaction is influenced by the component of verbal communication by pharmacists while providing counseling, with indicators of the tone of voice and body language, waiting time for counseling, and the atmosphere of the pharmacy (Fesharaki 2019). Furthermore, non-verbal communication such as maintaining eye contact, showing 
interest in providing information about drugs, and maintaining expression when interacting with patients should also be mastered. Counseling with verbal and non-verbal communication positively increases patient satisfaction since they feel happier while conversing with the pharmacists (Fesharaki 2019).

\section{Patient satisfaction with drug therapy monitoring services}

Table 3 displays eight articles on patient satisfaction with drug therapy monitoring services in clinical pharmacy. Generally, 7 articles showed high satisfaction, but one articles showed low patient satisfaction with clinical pharmacy services.

Patient satisfaction with drug therapy monitoring services in the United States is reported to have different levels. According to Martin and Faber (2016), 64 patients with Hepatitis C Virus (HCV) treatment had high satisfaction with drug therapy monitoring services by pharmacists. The clinical pharmacist-run HCV treatment program provides services to improve medication access, education about medications and adherence, and ADR management. Patients rate their overall satisfaction with the services provided in the "great" category (Martin and Faber 2016). This contrasts with the findings of Reich et al. (2018) study, that found that poor communication between prescribers and patients was the cause of low patient satisfaction (Reich et al. 2018).

According to Beyene et al. (2021) study in New Zealand, patients under warfarin drug therapy monitoring registered with the Community pharmacist-led Anticoagulant Management Service (CPAMS) were very satisfied with the drug delivery management services provided with the mean overall satisfaction score was $94.5 \% \pm 13.1$ (range $3 \%-100 \%)$. Furthermore, patient satisfaction was identified from factor analysis of patient-centered communication, pharmacist competence, patient-pharmacist relationship, confidence in CPAMS, and pharmacist environment. This study also stated that the increasing age and the more frequent visits to the pharmacy are positively related to patient satisfaction (Beyene et al. 2021).

Study of satisfaction with drug therapy monitoring services in South Africa on 300 patients with antiretroviral drug therapy monitoring for four months or more showed a high satisfaction level but patients expressed some dissatisfaction with certain dimensions of the quality of care, including an inability to talk to health workers about their treatment and problems, time spent in queues waiting to be examined and facility cleanliness (Bezuidenhout et al. 2014). In Canada, 107 out of 112 patients receiving chemotherapy were very satisfied with the monitoring regimen of chemotherapy drug therapy. This is influenced by satisfaction and follow-up care in chemotherapy patients. Satisfaction levels were very high in questions that evaluated the information provided by the pharmacist. A pharmacist led proactive follow-up program is an effective method for clinical pharmacy services (Crespo and Tyszka 2017).

Based on another study, patients in Taiwan with a history of more than one disease and monitored for therapy with more than one prescription had high satisfaction, as evidenced by a high level of confidence in pharmacists. Patient trust is positively related to patient satisfaction and cooperation between patients and clinical pharmacists. Thus, pharmacists should spend more time on each patient for can provide detailed information (Chou et al. 2019).

Table 3. Patient satisfaction with drug therapy monitoring services.

\begin{tabular}{|c|c|c|c|c|c|}
\hline Authors & Country & Participants & Factors that affect satisfaction & Result & Funding \\
\hline $\begin{array}{l}\text { Martin MT and } \\
\text { Faber D M, } 2016\end{array}$ & $\begin{array}{l}\text { United } \\
\text { States of } \\
\text { America }\end{array}$ & $\begin{array}{c}\text { A total of } 64 \text { patients received } \\
\text { Hepatitis C Virus (HCV) treatment }\end{array}$ & $\begin{array}{l}\text { HCV infection treatment as well as } \\
\text { compliance education }\end{array}$ & $\begin{array}{l}\text { Patients expressed high levels of satisfaction } \\
\text { with the clinical pharmacist who assisted them } \\
\text { with HCV treatment. }\end{array}$ & $\begin{array}{c}\text { Not } \\
\text { Applicable }\end{array}$ \\
\hline $\begin{array}{l}\text { Reich CM et al. } \\
2018\end{array}$ & $\begin{array}{l}\text { United } \\
\text { States of } \\
\text { America }\end{array}$ & $\begin{array}{l}\text { A total of } 240 \text { patients with } \\
\text { psychiatric disorders }\end{array}$ & $\begin{array}{l}\text { Satisfaction with antipsychotic drug } \\
\text { monitoring }\end{array}$ & $\begin{array}{l}\text { Conversations between prescribers and } \\
\text { psychiatric patients in which the prescriber } \\
\text { controls the conversational floor are a } \\
\text { symptom of low patients satisfaction. }\end{array}$ & $\begin{array}{c}\text { Not } \\
\text { Applicable }\end{array}$ \\
\hline $\begin{array}{l}\text { Crespo and } \\
\text { Tyszka } 2016\end{array}$ & Canada & $\begin{array}{l}\text { A total of } 112 \text { respondents were } \\
\text { chemotherapy patients }\end{array}$ & $\begin{array}{l}\text { Clinical pharmacy services and follow- } \\
\text { up care for chemotherapy patients }\end{array}$ & $\begin{array}{l}\text { 95.5\% of respondents indicated that the } \\
\text { time spent with the pharmacist at the first } \\
\text { chemotherapy treatment was worthwhile } \\
\qquad(\mathrm{n}=112) .\end{array}$ & $\begin{array}{c}\text { Not } \\
\text { Applicable }\end{array}$ \\
\hline $\begin{array}{l}\text { Beyene K et al. } \\
2020\end{array}$ & $\begin{array}{c}\text { New } \\
\text { Zealand }\end{array}$ & $\begin{array}{c}\text { A total of } 305 \text { respondents who } \\
\text { use Warfarin and are registered } \\
\text { with the Community pharmacist- } \\
\text { led Anticoagulation Management } \\
\text { Service (CPAMS) }\end{array}$ & $\begin{array}{l}\text { Patient satisfaction with CPAMS, } \\
\text { communication, patient confidence in } \\
\text { pharmacist competence, patient and } \\
\text { pharmacist relationship }\end{array}$ & $\begin{array}{l}\text { The mean overall satisfaction score was } 94.5 \% \\
\pm 13.1 \text { (range } 3 \%-100 \% \text { ). }\end{array}$ & $\begin{array}{c}\text { Not } \\
\text { Applicable }\end{array}$ \\
\hline $\begin{array}{l}\text { Bezuidenhout et } \\
\text { al. } 2014\end{array}$ & $\begin{array}{l}\text { South } \\
\text { Africa }\end{array}$ & $\begin{array}{l}\text { A total of } 300 \text { patients used } \\
\text { antiretrovirals }\end{array}$ & $\begin{array}{l}\text { Antiretroviral treatment (ART) } \\
\text { management satisfaction }\end{array}$ & $\begin{array}{l}\text { The majority of patients }(\mathrm{n}=297 ; 98 \%) \text { were } \\
\text { satisfied with the care they received at the ART } \\
\text { locations. }\end{array}$ & $\begin{array}{c}\text { Not } \\
\text { Applicable }\end{array}$ \\
\hline $\begin{array}{l}\text { Chou YC et } \\
\text { al.,2019 }\end{array}$ & Taiwan & $\begin{array}{l}\text { A total of } 741 \text { patients who } \\
\text { received medical care }\end{array}$ & $\begin{array}{l}\text { Patient confidence in doctors and } \\
\text { pharmacists, patient satisfaction }\end{array}$ & $\begin{array}{l}\text { Patient satisfaction and cooperation between } \\
\text { patients and clinical pharmacists are both } \\
\text { positively related to patient trust. }\end{array}$ & $\begin{array}{l}\text { Taiwan } \\
\text { National } \\
\text { Science } \\
\text { Council }\end{array}$ \\
\hline $\begin{array}{l}\text { Sites BD et al, } \\
2018\end{array}$ & Lebanese & $\begin{array}{l}\text { A total of } 19,566 \text { patients with } \\
\text { musculoskeletal disease }\end{array}$ & $\begin{array}{l}\text { Satisfaction with prescription opioids } \\
\text { use }\end{array}$ & $\begin{array}{l}\text { Patients who take prescribed opioids for } \\
\text { musculoskeletal pain are satisfied with their } \\
\text { treatment. }\end{array}$ & $\begin{array}{c}\text { Not } \\
\text { Applicable }\end{array}$ \\
\hline
\end{tabular}


In addition, a study in Lebanon on musculoskeletal patients who received more than one prescription stated the patients were satisfied with drug therapy services. This is influenced by satisfaction with pharmacist care for patients with musculoskeletal conditions, those using prescription opioids (Sites et al. 2018).

\section{Patient satisfaction with support program services}

Table 4 shows 3 articles on patient satisfaction with the support programs. Generally, the patients receiving the support program felt comfortable and reported high satisfaction.

According to Hatton et al. (2018) study in the United State, patients were satisfied with both Clinical Video Teleconferencing (CVT) and face-to-face consultations. The consultation through CVT did not differ from face-to face consultations. Factors that affect satisfaction were patient convenience level, patient satisfaction with pharmacist communication, competence, and clinical skills by pharmacist (Hatton et al. 2018).
In addition, a study in the United States was conducted by Mooney EV et al. (2018) on patients receiving aripiprazole, paliperidone, palmitate, and risperidone treatment. These patients were reported to have high satisfaction with the LAIA program with factors such as privacy, ease of making consultation appointments, convenience to pharmacy services, location convenience, and level of confidence in pharmacists (Mooney et al. 2018)

Another study concerning the patient support program conducted in Switzerland by Bourdin, A. et al. (2020) on 17 patients who participated in The Fingolimod Patient Support Program (F-PSP) program showed high satisfaction assessed based on safety and compliance with treatment using the F-PSP method. The pharmacistled consultations with medication-related and holistic support were well received by the patients. Patients' involvement in their health is boosted by consultations based on motivational technique and the use of provided tools. Furthermore, pharmacists tend to contribute significantly to patient management from the perspective of patients (Bourdin et al. 2020).

Table 4. Patient satisfaction with patient support program services.

\begin{tabular}{|c|c|c|c|c|c|}
\hline Authors & Country & Participants & Factors that affect satisfaction & Results & Funding \\
\hline $\begin{array}{l}\text { Hatton J et } \\
\text { al. } 2017\end{array}$ & $\begin{array}{c}\text { United } \\
\text { States of } \\
\text { America }\end{array}$ & $\begin{array}{c}57 \text { patients who received } \\
\text { care from the face-to-face or } \\
\text { clinical video teleconferencing } \\
\text { (CVT) pharmacy clinic. }\end{array}$ & $\begin{array}{l}\text { Patient convenience level, patient } \\
\text { satisfaction with communication } \\
\text { made with the clinical } \\
\text { pharmacistcompetence and skills }\end{array}$ & $\begin{array}{l}\text { Patients are satisfied with clinical } \\
\text { pharmacists' use of patient-centered } \\
\text { communication via both CVT and } \\
\text { face-to-face consultations. }\end{array}$ & Not Applicable \\
\hline $\begin{array}{l}\text { Mooney EV } \\
\text { et al. } 2018\end{array}$ & $\begin{array}{l}\text { United } \\
\text { States of } \\
\text { America }\end{array}$ & $\begin{array}{l}161 \text { patients received LAIA } \\
\text { (Long-Acting Injectable } \\
\text { Antipsychotics). }\end{array}$ & $\begin{array}{l}\text { The level of privacy, the ease of } \\
\text { making consultation appointments, } \\
\text { convenience to pharmacy services, } \\
\text { location convenience, the level of } \\
\text { confidence in the pharmacist }\end{array}$ & $\begin{array}{l}\text { Patients are satisfied with the LAIA } \\
\text { services provided by pharmacists in } \\
\text { community pharmacies. }\end{array}$ & Not applicable \\
\hline $\begin{array}{l}\text { Bourdin A } \\
\text { et al. } 2020\end{array}$ & Switzerland & $\begin{array}{l}17 \text { patients participated in } \\
\text { F-PSP (The Fingolimod Patient } \\
\text { Support Program). }\end{array}$ & $\begin{array}{l}\text { The level of patient safety and } \\
\text { medication compliance with the } \\
\text { F-PSP (Fingolimod Patient Support } \\
\text { Program) method }\end{array}$ & $\begin{array}{c}\text { Patients satisfied with F-PSP } \\
\text { (The Fingolimod Patient Support } \\
\text { Program) }\end{array}$ & $\begin{array}{l}\text { The development of the F-PSP } \\
\text { is supported by an unlimited } \\
\text { grant from Novartis Pharma } \\
\text { Schweiz AG. }\end{array}$ \\
\hline
\end{tabular}

\section{Patient satisfaction with pharmaceutical care services}

Table 5 shows seven articles that discuss patient satisfaction with pharmaceutical care services. While 6 of 7 articles show high patient satisfaction, 1 article shows low patient satisfaction.

In the United Arab Emirates (UAE), a study conducted by El-Sharif et al. (2017) reported that $77.1 \%$ of patients were satisfied with pharmaceutical care services. This is influenced by several factors, such as experience, trust, courtesy, and confidence of pharmacists when providing pharmaceutical services. However, there are still many patients who are not aware of what information is expected and should be received regarding the drugs they receive from pharmacists. Therefore, pharmacists need to fully practice their role for the benefit of their patients (El-Sharif et al. 2017). Another study in the UAE was also conducted by Saad Ali et al., (2019) reported that $72.8 \%$ of patients were very satisfied with simple, understandable language used by the pharmacists. However, the patients were not satisfied with the privacy while pharmacists discussed with patients (Saad Ali et al. 2019).

In a study conducted by Abebe et al. (2016) in Ethiopia on $291 \mathrm{HIV} /$ AIDS patients using a type 5 Likert scale instrument through interviews, patient satisfaction was reported to be relatively low with an average satisfaction level of 2.46 out of a 5-point Likert scale. Meanwhile, overall patient expectations for pharmaceutical services are very high. This is influenced by uncomfortable waiting rooms, private counseling rooms, and waiting times (Abebe et al. 2016).

The study conducted by Soeiro, O.M., et al. (2017) on 8,803 patients in five geopolitical regions of Brazil stated that $58.4 \%$ were satisfied with the services received. This is influenced by the patients' comfort feeling when communicating with pharmacists (Soeiro et al. 2017).

Another study was also conducted by Minarikova, et al. (2016) in Slovakia, using a type 5 Likert scale instrument. A total of 2,844 patients reported that overall patients were very satisfied with pharmaceutical care services: interpersonal relationships $(1.85 \pm 0.598 ; 86.7 \%$ 
Table 5. Patient satisfaction with pharmaceutical care services.

\begin{tabular}{|c|c|c|c|c|c|}
\hline Authors & Country & Number of samples & Factors that affect satisfaction & Results & Funding \\
\hline $\begin{array}{l}\text { El-Sharif SI } \\
\text { et al. } 2017\end{array}$ & $\begin{array}{c}\text { United } \\
\text { Arab } \\
\text { Emirates }\end{array}$ & $\begin{array}{l}\text { A total of } 375 \text { patients with medical } \\
\text { and non-medical educational } \\
\text { backgrounds }\end{array}$ & $\begin{array}{l}\text { Satisfaction with pharmaceutical care } \\
\text { services }\end{array}$ & $\begin{array}{l}77.1 \% \text { of patients are satisfied with the } \\
\text { pharmacist's assistance. }\end{array}$ & Not Applicable \\
\hline $\begin{array}{l}\text { Ali HS et al. } \\
2019\end{array}$ & $\begin{array}{l}\text { United } \\
\text { Arab } \\
\text { Emirates }\end{array}$ & $\begin{array}{l}\text { A total of } 210 \text { respondents who } \\
\text { came to pharmacy }\end{array}$ & $\begin{array}{l}\text { The convenience of pharmacists in } \\
\text { providing pharmaceutical care services }\end{array}$ & $\begin{array}{l}39 \% \text { patients were highly satisfied with } \\
\text { the professional pharmacists' counselling } \\
\text { profile and } 72.8 \% \text { satisfied with the simple, } \\
\text { understandable language used by the } \\
\text { pharmacists. }\end{array}$ & Not Applicable \\
\hline $\begin{array}{l}\text { Soeiro OM } \\
\text { et al. } 2017\end{array}$ & Brazil & $\begin{array}{l}\text { A total of } 8,803 \text { patients present in } \\
\text { the five geopolitical regions of Brazil }\end{array}$ & $\begin{array}{l}\text { Convenience, availability of } \\
\text { pharmaceutical care services }\end{array}$ & $\begin{array}{l}58.4 \% \text { patients satisfied with the } \\
\text { pharmaceutical care services }\end{array}$ & $\begin{array}{l}\text { Department for } \\
\text { Pharmaceutical } \\
\text { Services and } \\
\text { Strategic }\end{array}$ \\
\hline $\begin{array}{l}\text { Takaki H et } \\
\text { al. } 2015\end{array}$ & Japan & $\begin{array}{c}\text { A total of } 407 \text { patients in Fukuoka } \\
\text { Prefecture, Japan }\end{array}$ & $\begin{array}{l}\text { Pharmaceutical care service information } \\
\text { satisfaction }\end{array}$ & $\begin{array}{c}\text { Patient satisfaction with pharmaceutical } \\
\text { care was linked to pharmacist and patient } \\
\text { views of information provision. }\end{array}$ & Not Applicable \\
\hline $\begin{array}{l}\text { Abebe TB et } \\
\text { al. } 2016\end{array}$ & Ethiopia & $\begin{array}{c}\text { A total of } 291 \text { patients living with } \\
\text { HIV/AIDS }\end{array}$ & $\begin{array}{l}\text { The level of privacy, the ease of making } \\
\text { consultation appointments, the } \\
\text { convenience of pharmaceutical care } \\
\text { services }\end{array}$ & $\begin{array}{l}\text { Patient satisfaction is relatively low with an } \\
\text { average satisfaction of } 2.86,2.88 \text {, and } 2.99 \\
\text { from 5-point Likert-type scale }\end{array}$ & Not applicable \\
\hline $\begin{array}{l}\text { Minarikova } \\
\text { et al. } 2016\end{array}$ & Slovakia & $\begin{array}{c}\text { A total of } 2844 \text { respondents aged } 40 \\
\text { years and over }\end{array}$ & $\begin{array}{l}\text { Location of pharmacy services, patient } \\
\text { experience with qualified pharmacists } \\
\text { and staff convenience, health checks, and } \\
\text { self-service areas. }\end{array}$ & $\begin{array}{l}\text { The results show high patient satisfaction } \\
\text { with pharmaceutical services, specifically } \\
\text { interpersonal relationships. }\end{array}$ & Not Applicable \\
\hline
\end{tabular}

highly satisfied respondents) and general satisfaction (2.02 $\pm 0.643 ; 71.3 \%$ highly satisfied respondents). Managing therapy received a lower score $(2.24 \pm 0.704$; $65.4 \%$ highly satisfied respondents). Prescription $(70.4 \%)$ and over-the-counter drugs were the most common reasons for visiting a community pharmacy (70.4\%) (Mináriková et al. 2016). Therefore, pharmacists need to improve their professional behavior in providing pharmaceutical care to patients.

\section{Limitation}

This literature review has several limitations. First, because of insufficient information about the health care system in countries where studies were conducted, this review does not discuss the difference in the health care system that could lead to different satisfaction levels. Second, the level of satisfaction could not be generalized, because the different cultures could influence the level of satisfaction of patients. However, this article could give an overview of patient satisfaction with clinical pharmacy services and the affecting factors.

\section{References}

Abebe TB, Erku DA, Gebresillassie BM, Haile K, Mekuria AB (2016) Expectation and satisfaction of HIV/AIDS patients toward the pharmaceutical care provided at Gondar University Referral Hospital, Northwestern Ethiopia: a cross-sectional study. Patient Preference and Adherence 10: 2073-2082. https://doi.org/10.2147/PPA.S114720

Al-Arifi MN (2012) Patients' perception, views and satisfaction with pharmacists' role as health care provider in community pharmacy setting at Riyadh, Saudi Arabia. Saudi Pharmaceutical Journal 20(4): 323-330. https://doi.org/10.1016/j.jsps.2012.05.007

\section{Conclusion}

In general, most patients are satisfied with clinical pharmacy services such as counseling, drug therapy monitoring, patient support programs, and pharmaceutical care. In addition, pharmaceutical service quality, convenience, information easiness, and patient confidence in pharmacist competence primarily influence patient satisfaction with clinical pharmacy services. Therefore, in the future, community pharmacists should equip themselves with the appropriate knowledge and competencies in clinical pharmacy services for benefit their patients.

\section{Funding}

There is no funding for this study.

\section{Conflict of interest}

This study has no conflict of interest.

Alkhoshaiban A, Hassan Y, Loganathan M, Alomary M, Morisky DE, Alawwad B (2019) Type II Diabetic Patients' Satisfaction, Medication Adherence, and Glycemic Control after the Application of Pharmacist Counseling Program. 10 pp.

Alotaibi NH, Alzarea AI, Alotaibi AM, Khan YH, Mallhi TH, Alharbi KS, Alruwaili NK, Alanazi AS, Hassan A, Alotaib BS (2021) Exploring satisfaction level among outpatients regarding pharmacy facilities and services in the Kingdom of Saudi Arabia; a large regional analysis. PLoS ONE 16(4): e0247912. https://doi.org/10.1371/journal.pone.0247912 
Ansari M (2017) Evaluation of community pharmacies regarding dispensing practices of antibiotics in two districts of central Nepal. PLoS ONE 12(9): e0183907. https://doi.org/10.1371/journal.pone.0183907

Beyene K, Chan AHY, Bandreddi NST, Tabar RB, Moyle E, Nath S, Wang N, Harrison J (2021) Patient satisfaction with community pharmacist-led anticoagulation management services and its relationship with patient characteristics in New Zealand. International Journal of Clinical Pharmacy 43(1): 154-164. https://doi.org/10.1007/s11096-020-01124-y

Bezuidenhout S, Ogunsanwo DA, Helberg EA (2014) Patient satisfaction at accredited antiretroviral treatment sites in the Gert Sibande District. African Journal of Primary Health Care \& Family Medicine 6(1): a627. https://doi.org/10.4102/phcfm.v6i1.627

Bourdin A, Dubois J, Foley RA, Schluep M, Bugnon O, Berger J (2020) Satisfaction and experiences of patients taking fingolimod and involved in a pharmacy-based patient support program in Switzerland - a qualitative study. BMC Health Services Research 20(1): e425. https://doi.org/10.1186/s12913-020-05278-3

Chou Y-C, Dang VT, Yen H-Y, Lai K-M (2019) Influence of Risk of DrugDrug Interactions and Time Availability on Patient Trust, Satisfaction, and Cooperation with Clinical Pharmacists. International Journal of Environmental Research and Public Health 16(9): e1566. https://doi. org/10.3390/ijerph16091566

Crespo A, Tyszka M (2017) Evaluating the patient-perceived impact of clinical pharmacy services and proactive follow-up care in an ambulatory chemotherapy unit. Journal of Oncology Pharmacy Practice 23(4): 243-248. https://doi.org/10.1177/1078155216634180

El-Sharif S, Alrahman N, Khaled N, Sayah N, Gamal E, Mohamed A (2017) Assessment of patient's satisfaction with pharmaceutical care services in community pharmacies in the United Arab Emirates. Archives of Pharmacy Practice 8(1): e22. https://doi.org/10.4103/2045-080X.199615

Fesharaki F (2019) Nonverbal communication of pharmacists during counseling leading to patient satisfaction: evidence from Iranian retail market. Atlantic Journal of Communication 27(1): 62-73. https://doi.org/10.1080/15456870.2019.1540241

Garattini L, Padula A (2018) Pharmaceutical care in Italy and other European countries: between care and commerce? Postgraduate Medicine 130(1): 52-54. https://doi.org/10.1080/00325481.2018.1399043

Gulcan C, Aransiola DA (2019) Review on patient satisfaction in pharmacy services. EMU Journal of Pharmaceutical Sciences 1(1): 68-75

Hale A, Coombes I, Stokes J, Aitken S, Clark F, Nissen L (2016) Patient satisfaction from two studies of collaborative doctor - pharmacist prescribing in Australia. Health Expectations 19(1): 49-61. https://doi.org/10.1111/hex.12329

Hall JJ, Katz SJ, Cor MK (2017) Patient Satisfaction with PharmacistLed Collaborative Follow-Up Care in an Ambulatory Rheumatology Clinic. Musculoskeletal Care 15(3): 186-195. https://doi.org/10.1002/ msc. 1160

Hatton J, Chandra R, Lucius D, Ciuchta E (2018) Patient Satisfaction of Pharmacist-Provided Care via Clinical Video Teleconferencing. Journal of Pharmacy Practice 31(5): 429-433. https://doi. org/10.1177/0897190017715561

Hillier-Brown F, Bambra C, Thomson K, Balaj M, Walton N, Todd A (2017) The effects of community pharmacy public health interventions on population health and health inequalities: a systematic review of reviews protocol. Systematic Reviews 6(1): e176. https://doi.org/10.1186/s13643-017-0573-9

Iancu ME, Bucsa C, Farcas AM, Leucuta DC, Dincu A, Bojita MT (2014) Counseling provided by the pharmacist in Romanian community pharmacy: the patients' perspective. Medicine and Pharmacy Reports 87(2): 113-118. https://doi.org/10.15386/cjmed-257

Kabba JA, Bah AJ, James PB, Chang J, Kitchen C, Jiang M, Zhao M, Fang Y (2021) Patients satisfaction with free healthcare pharmaceutical services in Sierra Leone: a national cross-sectional study. International Journal of Clinical Pharmacy 43(3): 556-565. https://doi.org/10.1007/ s11096-020-01163-5

Kooy MJ, van Geffen EC, Heerdink ER, van Dijk L, Bouvy ML (2014) Effects of a TELephone Counselling Intervention by Pharmacist (TelCIP) on medication adherence, patient beliefs and satisfaction with information for patients starting treatment: study protocol for a cluster randomized controlled trial. BMC Health Services Research 14(1): e219. https://doi.org/10.1186/1472-6963-14-219

Malewski DF, Ream A, Gaither CA (2015) Patient satisfaction with community pharmacy: Comparing urban and suburban chain-pharmacy populations. Research in Social and Administrative Pharmacy 11(1): 121-128. https://doi.org/10.1016/j.sapharm.2014.05.001

Martin MT, Faber DM (2016) Patient satisfaction with the clinical pharmacist and prescribers during hepatitis $\mathrm{C}$ virus management. Journal of Clinical Pharmacy and Therapeutics 41(6): 645-649. https://doi.org/10.1111/jcpt.12436

Miller R, Goodman C (2016) Performance of retail pharmacies in lowand middle-income Asian settings: a systematic review. Health Policy and Planning 31(7): 940-953. https://doi.org/10.1093/ heapol/czw007

Mináriková D, Malovecká I, Lehocká L, Snopková M, Foltán V (2016) The Assessment of Patient Satisfaction and Attendance of Community Pharmacies in Slovakia. European Pharmaceutical Journal 63(2): 23-29. https://doi.org/10.1515/afpuc-2016-0002

Mooney EV, Hamper JG, Willis RT, Farinha TL, Ricchetti CA (2018) Evaluating patient satisfaction with pharmacist-administered long-acting injectable antipsychotics in the community pharmacy. Journal of the American Pharmacists Association 58(4): S24-S29. https://doi.org/10.1016/j.japh.2018.04.035

Munro L, Myers G, Gould O, LeBlanc M (2021) Clinical pharmacy services in an ambulatory oncology clinic: Patient perception and satisfaction. Journal of Oncology Pharmacy Practice 27(5): 10861093. https://doi.org/10.1177/1078155220950412

Page MJ, McKenzie JE, Bossuyt PM, Boutron I, Hoffmann TC, Mulrow CD, Shamseer L, Tetzlaff JM, Akl EA, Brennan SE, Chou R, Glanville J, Grimshaw JM, Hróbjartsson A, Lalu MM, Li T, Loder EW, MayoWilson E, McDonald S, McGuinness LA, Stewart LA, Thomas J, Tricco AC, Welch VA, Whiting P, Moher D (2021) The PRISMA 2020 statement: an updated guideline for reporting systematic reviews. https://doi.org/10.31222/osf.io/v7gm2

Reich CM, Hack SM, Klingaman EA, Brown CH, Fang LJ, Dixon LB, Jahn DR, Kreyenbuhl JA (2018) Consumer satisfaction with antipsychotic medication-monitoring appointments: the role of consumer-prescriber communication patterns. International Journal of Psychiatry in Clinical Practice 22(2): 89-94. https://doi.org/10.108 0/13651501.2017.1375530

Saad Ali H, Aldahab AS, Mohamed EB., Prajapati SK, Badulla WF, Alshakka M, Baig MR (2019) Patients' Perspectives on Services Provided by Community Pharmacies in Terms of Patients' Perception and Satisfaction. Journal of Young Pharmacists 11(3): 279-284. https://doi.org/10.5530/jyp.2019.11.56

Schoenfelder T, Klewer J, Kugler J (2011) Determinants of patient satisfaction: a study among 39 hospitals in an in-patient setting in 
Germany. International Journal for Quality in Health Care 23(5): 503-509. https://doi.org/10.1093/intqhc/mzr038

Sites BD, Harrison J, Herrick MD, Masaracchia MM, Beach ML, Davis

MA (2018) Prescription Opioid Use and Satisfaction With Care Among Adults With Musculoskeletal Conditions. The Annals of Family Medicine 16(1): 6-13. https://doi.org/10.1370/afm.2148

Soeiro OM, Tavares NUL, do Nascimento Jr JM, Guerra Jr AA, Costa EA, de Assis Acurcio F, Guibu IA, Álvares J, de Oliveira Karnikowski MG, Leite SN, Costa KS (2017) Patient satisfaction with pharmaceutical services in Brazilian primary health care. Revista de Saúde Pública 51: e21. https://doi.org/10.11606/S15188787.2017051007145

Upadhyay DK, Mohamed Ibrahim MI, Mishra P, Alurkar VM (2015) A non-clinical randomised controlled trial to assess the impact of pharmaceutical care intervention on satisfaction level of newly diagnosed diabetes mellitus patients in a tertiary care teaching hospital in Nepal. BMC Health Services Research 15(1): e57. https://doi.org/10.1186/s12913-015-0715-5 